\title{
EFFECT OF HUMIC ACID AND SEAWEEDS EXTRACTS ON GROWTH, YIELD AND NUTRIENT CONTENT OF GARLIC (Allium sativum L.)
}

\author{
KURDISTAN HASSAN YOUSIF * \\ Dept. of Horticulture, College of Agriculture, University of Duhok, Kurdistan Region-Iraq
}

(Received: January 9, 2018; Accepted for publication: May 7, 2018)

\begin{abstract}
This study was done in the winter growing season of 2016 in the college of Agriculture University of Dohuk।Kurdistan region .Iraq, to determine the effects of humic acid with four concentrations $(0,0.5,1,1.5$ g.. ${ }^{-1}$ ) and seaweeds extract (Alga 600) with two concentrations $\left(0\right.$ and $8 \mathrm{ml}^{-L^{-1}}$ ) on Garlic (Allium sativum L.) $\mathrm{cv}$. Chinese. Results indicated that spraying of humic acid $\left(1.5 \mathrm{~g} . \mathrm{L}^{-1}\right)$ significantly increase vegetative growth characteristic which regarded on leaves number.plant ${ }^{-1}(6)$ stem diameter $(5.6 \mathrm{~mm})$ and chlorophyll content (69.78 SPAD) were significantly increased as compared with untreated plant $\left(65.5 \mathrm{~cm}, 4.55\right.$ leave.Plant ${ }^{-1}, 3.83$ cm and (57.28 SPAD). The same concentration also showed significant effect on yield and bulb quality and recorded the highest value of (cloves weight $(4.9 \mathrm{~g})$ cloves number.bulb ${ }^{-1}(97.67)$ 'bulbs weight $(28.47 \mathrm{~g})$ and bulbs length $(4,28 \mathrm{~cm})$,cloves length $(2.72 \mathrm{~cm})$ and cloves diameter $(2.67 \mathrm{~cm})$ compared with untreated plants, also humic acid showed significantly increase in nutrient percentage (N,P and $A)$ in bulbs of garlic. In the other hand, seaweed extracts also showed significant effect of all studied characteristic, since spraying of seaweed extracts at $\left(8 \mathrm{~m} . \mathrm{L}^{-1}\right)$ recorded the highest value of (vegetative growth characteristic, yield and quality characteristic as compared with untreated plants. For the interaction, results showed that the interaction of $\left(1.5 \mathrm{~g} . \mathrm{L}^{-1}\right)$ of humic acid with $\left(8 \mathrm{ml} . \mathrm{L}^{-1}\right)$ of seaweed extracts recorded the highest values of the vegetative growth, yield and nutrient content.
\end{abstract}

KEYWORDS: Garlic (Allium sativum L.), Humic acids, Seaweeds extract, yield, nutrient content.

\section{INTRODUCTION}

G arlic (Allium sativum L.) is one member of the onion family, has been cultivated for thousands of years and is widely used for culinary and medicinal purposes (Hahn, 1996). The Iraqi problems of its soil that characterized with the basic nature and its poorly in organic matter and what is associated with it of nutrient elements fixation and then affected on yield of crops, so it is necessary to search for other ways for plant nutrition like organic fertilizers such as humic acid and seaweeds extracts (Abdel-Razzak and El-Sharkawy, 2013).The total production is increased slowly in past few years, so, the garlic bulb yield could be enhanced by improving the agriculture treatments. However, advances and improvement in this trend must be continued and more environmental friendly production must be followed. Some environmental-friendly products that has been widely used in agricultural applications.
Increasing safe food production is a global demand, also, increasing yield is the most important Agro-economic goal of farmers. Conventional macro and micro elements fertilization has a superior effect on plant growth and yield, but these are expensive and environmentally hazardous due to leaching out, contamination of the subsurface water and water basins and damaging beneficial microorganisms (Hilman and Asandhi, 1987). One of the organic farming strategies is natural minerals as a source of nutrients.

Some substances affected on plant growth and its physiological activities, Including humic acid which promote plant growth and induce soil microorganisms like bacteria and fungi and provide carbon as a source for the organisms humic acid as well acting as chelating good martial, and reason the lack of mineral nutrient, losing them by leaching ,also make many nutrient available in soil such as phosphate, calcium and trace elements and humic acid possesses high

*Kurdistan_solyvany@yahoo.com 
capability in controlling soil $\mathrm{pH}$ against changes which might occurs for the use of chemical fertilizer (Leonard, 2008). Humic acid is a complex molecule and is considered an alkali soluble, polymeric organic acid of aromatic structure substituted by carboxyl, phenolic, hydroxyl and alkyl groups linked together by ester linkages (Gaines and Yilmaz, 1983). Humic substances are formed through the process of humification of organic materials as by-product of microbial metabolism and are found in soil, coal, sediments water, peat and organic matter (Stevenson, 1994).

Jensen (2004) reported that seaweed extracts contain various micro elements $(\mathrm{Cu}, \mathrm{Zn}, \mathrm{B}, \mathrm{Co})$ in addition to macro elements and contain Auxins, Gibberellins' and Cytokinins, when spray on plants lead to increase root growth ability, nutrient elements absorption, andstem thickness and growth significantly.

Eris et al (2008) showed that seaweed extracts when sprayed on pepper plants lead to increase growth, yield and concentration of some nutrient elements significantly. Zhang and Ervin (2004) found that the influence of Cytokinin of seaweed extracts and Humic acid tended to improve the resistance of herbaceous plant to drought condition and to increase Cytokinin content and its physiological role in plant.

The aim from this study is to know the effects of humic acid and seaweeds extracts (Alge 600 ) on growth, yield, and nutrient content of garlic chaines spp.

\section{MATERIALS AND METHODS}

The experiment was done on $1^{\text {st }}$ December-30 May 2016, at the research farm, College of Agriculture, on Garlic (Allium sativum L.) Chinese cultivar, the land was ploughed for two perpendicular lines and the soil was well lofted, the whole area was divided in to three blocks, each experiment units consist of three row of $2 * 1$ $\mathrm{m}$. bulbs were planted at distances of $25 \mathrm{~cm}$, at the third upper part of the two side of the ridge the fertilizer process by adding animal manure before planting and the soil was irrigated then the bulbs was planted. Randomize Completely Block design (R.C.B.D.) was used in this study that experiment included two factor, the first one was the concentration of humic acid $(0$ and $0.5,1$ and 1.5 g. $\left.\mathrm{L}^{-1}\right)$ and the other one represent the seaweeds extracts with two concentration $\left(0\right.$ and $\left.8 \mathrm{ml} . \mathrm{L}^{-1}\right)$, after one month of planting the plant were sprayed three times within 10 day intervals on the other hand all needed agricultural and horticultural process was done regularly during this study, the obtained data was statistically analyzed by using SAS program, and the significant difference between means was evaluated according to Duncan multiple range test at $5 \%$ level. The experimental traits was as follows:

1. Vegetative growth characteristic, that include:

Leaves length $(\mathrm{cm})$, leaves number.plant ${ }^{1}$,stem diameter(mm), chlorophyll SPAD) (It was determined by using Spad Meter -502, Konica Minolta).

3. Yield characteristic of garlic , that include: Cloves weight (g), cloves number and bulbs weight $(\mathrm{g})$.

4. Quality characteristic of garlic that include: Bulbs diameter $(\mathrm{cm})$, bulbs length $(\mathrm{cm})$, cloves length $(\mathrm{cm})$ and cloves diameter $(\mathrm{cm})$.

5. Nutrient contents of garlic, that include:

Total nitrogen were determined according to (A.O.A.C, 2000) Phosphorus According to colorimetric method using Spectrophotometer (Matt, 1970) and K According to flame method using Flame photometer instrument (A.O.A.C, 2000).

\section{RESULTS AND DISSCUTION: 3. 1. Characters Of Vegetative Growth:}

Table (1) Refer to the effect of humic acid and seaweeds extracts and their interaction on vegetative growth characteristic, the data showed that there was significant differences according to the concentration of humic acid treating plant with $\left(1 \mathrm{~g} . \mathrm{L}^{-1}\right)$ of humic acid gave significant increase in leaves length $(\mathrm{cm})$ as compared with untreated plant (61 and $56.5 \mathrm{~cm}$ ). Regarding the effect of Seaweeds extracts with regard to leaves length which reaches (62.3 leaves.plant-1) compared with untreated plant, on the other hand the effect of interaction between the treatment and seaweeds extract indicated that there was significant difference in the $\left(1 \mathrm{~g} . \mathrm{L}^{-1}\right)$ of humic acid and $\left(8 \mathrm{ml} . \mathrm{L}^{-1}\right)$ seaweeds extracts that gave highest leave length $(67.67 \mathrm{~cm})$ compared with untreated one $(53.67 \mathrm{~cm})$. Treating plant with concentration $\left(1 \mathrm{~g} . \mathrm{L}^{-1}\right)$ of humic acid appear significantly effects on regard leaves length which gave $(65.5 \mathrm{~cm})$ compared with untreated plants that gave lower value $(56.5 \mathrm{~cm})$. 
Treating plant with humic acid at concentration $(0.5$, 1 and 1.5 g.L L $^{-1}$ ) showed significant different compared with untreated plants that gave lower value. Leaves number.plant ${ }^{-1}$ treating plant with seaweed extracts gave significant different compared with untreated ones $(6.17$ and 4.85 leaves.plant $\left.{ }^{-1}\right)$ respectively, regarding the interaction between humic acid and seaweeds extracts it was appeared that interaction among humic acid concentration and seaweeds extracts showed significant increased that gave high number of leaves as compared with control.

Treating plant with $\left(1.5\right.$ g.L $\left.\mathrm{L}^{-1}\right)$ of humic acid gave high diameter $(5.87 \mathrm{~mm})$ as compared with control that gave lower value of diameter $(3.83 \mathrm{~mm})$. .Results showed significant different when using seaweeds extracts $\left(8 \mathrm{ml} \cdot \mathrm{L}^{-1}\right)$ as compared with untreated plant (control) (5.32 and $4.55 \mathrm{~mm}$ ) respectively. The interaction among treatments showed significant different treating plants with (1 and $\left.1.5 \mathrm{~g} . \mathrm{L}^{-1}\right)$ that gave high diameter of stem $(8.88$ and $8.87 \mathrm{~mm}$ ) respectively compared with untreated plant that gave lower value $(3.13 \mathrm{~mm})$.

Table (1) showed that there were significant effect of seaweeds extract on chlorophyll content, treated plants with seaweeds extracts recorded (68.35 and SPAD) and untreated plant recorded (60.93 and SPAD).

In the same time there was significant differences as a result of the concentration of humic acid on the chlorophyll content, the effect of interaction between the treatments indicated that there was significant difference in the interaction with $\left(1.5 \mathrm{~g} . \mathrm{L}^{-1}\right)$ of humic acid and seaweeds extracts $8 \mathrm{ml} . \mathrm{L}^{-1}$ that gave higher value of chlorophyll content which recorded (74.8 SPAD) compared with untreated plants treatments that gave lower value (51.67 SPAD).

Increasing vegetative growth may be due to the seaweeds extracts and humic acid that attributed to the influence of humic acid which provides nutrient minerals that involve in plants bioactivities and finally leads to growth induction (Abdel Mawgaud et al., 2007). Furthermore, humic acid increases the porosity of soil and improve growth of root system which leads to increase the shoot system of crop (Garcia et al, 2008). Humic acid degrade soil, improve its physical, chemical, biological and nutritional characteristics by degrading clay particles and increasing holding water capacity. Seaweed extracts contain cytokinins as well in which induce the physiological activities (for instance activating some enzymes that involved in photosynthesis) and increase the total chlorophyll in the plant, this will positively Reflect on the activity of photosynthesis and the synthesized materials which will positively reflect on shoots characteristics (Thomas, 1996).This increase in shoots characteristics might also due to the macronutrients content in seaweed extracts. Macronutrients have a great role in plant nutrition like nitrogen, potassium and phosphorous which are very essential for the growth and development of the plant (Attememe, 2009).The positive effect of Actosol and humic acid addition on plant growth and chlorophyll content may be due to containing of humic acid certain nutrients which are correcting the widespread occurrence of deficiency symptoms. This is attainted through increasing the soil water holding capacity, promoting soil structure and enhances the metabolic activity of microorganisms.

\subsection{Yield Characteristics:}

Table (2) Indicated to the effect of humic acid ,seaweeds extracts and their interaction on yield characteristic of garlic(cloves weight (g), cloves diameter $\mathrm{cm}$, bulbs weight $(\mathrm{g})$, results showed significant increased on regard of cloves weight (g)., treating plant with different concentration of humic acid were gave significant increase compared with untreated plant that gave lower weight of cloves $\left(3.70\right.$ g..$\left.^{-1}\right)$. Treating plant with $8 \mathrm{ml} . \mathrm{L}^{-1}$ seaweeds extract gave high weight of cloves compared with untreated plant (4.6 and $4.38 \mathrm{~g}$ ) respectively.

Regarding the interaction among treatments it was appeared significant different between the seaweeds extracts and humic acid levels, interaction between $\left(1.5\right.$ g. $\left.\mathrm{L}^{-1}\right)$ of humic acid and $\left(8 \mathrm{ml} . \mathrm{L}^{-1)}\right.$ of seaweeds extracts gave high weight of cloves compared with untreated interaction with humic acid and seaweeds extracts (5 and $3.83 \mathrm{~g})$ respectively.

Data in table (2) refer the significant different among treatment on regard cloves number.bulbs ${ }^{-1}$ treating plant with $\left(8 \mathrm{ml} . \mathrm{L}^{-1}\right)$ seaweeds extracts (7.58 cloves.bulbs $\left.{ }^{-1}\right)$ compared with untreated plant $\left(6.83\right.$ cloves.bulbs $\left.^{-1}\right)$, about the interaction among treatment the best interaction among them was when plant treated with $\left(1.5 \mathrm{~g} . \mathrm{L}^{-1}\right)$ humic acid with $\left(8 \mathrm{ml} . \mathrm{L}^{-1}\right)$ Seaweeds extracts that gave high number of cloves .bulbs ${ }^{-1}$ (9.79) compared with untreated interaction with humic acid and seaweeds extract that gave lower value (5.33cloves.bulbs ${ }^{-1}$ ).

Plant treated with levels of humic acid gave significant different among them concentration (1 
and 1.5 g.. $\mathrm{L}^{-1}$ ) of humic acid gave high weight of bulbs $\left(28.47\right.$ and 28.00 g.bulb $\left.^{-1}\right)$ respectively as compared with untreated plant with humic acid (22.67g.bulbs $\left.{ }^{-1}\right)$. There are significant different among treatment with regard of bulbs weight $(\mathrm{g})$ treating plant with $\left(8 \mathrm{ml} . \mathrm{L}^{-1}\right)$ gave high weight of bulbs compared with untreated plant with seaweeds extracts(27.33 and $24.1 \mathrm{~g})$ respectively. Regarding the interaction between treatments the interaction among humic acid concentration and seaweeds extracts gave significant different.

Treating plant with $\left(1.5\right.$ g. $\left.\mathrm{L}^{-1}\right)$ of humic acid and $\left(8 \mathrm{ml} . \mathrm{L}^{-1}\right)$ gave high weigh of bulb $(31.93 \mathrm{~g})$ as compared with other interaction especially untreated interaction with humic acid and seaweeds extract ( $22.50 \mathrm{~g}$.).

In the same time there was significant increase on yield as a result of the concentration of humic acid on the other hand the effect of interaction between the treatment indicated that there was significant difference in the interaction among spraying humic acid concentration (1.5 g. $\left.\mathrm{L}^{-1}\right)$ with $\left(8 \mathrm{ml} . \mathrm{L}^{-1}\right)$ of seaweeds extracts that gave high value of yield $\mathrm{kg} . \mathrm{m}^{2}\left(127.72 \mathrm{~kg} \cdot \mathrm{m}^{2}\right.$ compared with the other treatments especially especially untreated plants which gave lower value of yield $\left(90 \mathrm{~kg} \cdot \mathrm{m}^{2}\right)$.

Results of the total yield $\left(\mathrm{kg} \cdot \mathrm{m}^{2}\right)$ of garlic were also refers that the adding seaweeds extracts showed significant increase when using $\left(8 \mathrm{mll}^{-1} \mathrm{~L}^{-1}\right)$ of seaweeds extract which reaches $\left(109.32 \mathrm{~kg} . \mathrm{mt}^{2}\right)$ in compared with $\left(96.6 \mathrm{~kg} . \mathrm{mt}^{2}{ }^{2}\right)$ in untreated plant,

Humic acid is a commercial product contains many elements which were improve the soil fertility and increase the availability of nutrient elements by holding them on mineral surfaces, consequently, affect plant growth and yield (ElSharkawy and Abdel-Razzak, 2010). As well as, El-Bassiony et al. 2010 and El-Nemer et al. 2012 on sweet pepper plants. The same trend was found by, Abdel-Razzak and El-Sharkawy, 2013they concluded that garlic plants which were sprayed with humic acid at $2 \mathrm{~g} / \mathrm{L}$ for two times showed superior effect for increasing garlic productivity.

The increase in yield may be due to the effect of seaweeds extracts, using of seaweed products improve seeds germination, seedlings development, increase plant tolerance to environmental stresses (Zhang and Ervin, 2004), and enhance plant growth and yield (Hong et al,2007; Zodape et al, 2008; Kumari et al,2011; Craigie, 2011). Liquid extracts obtained from seaweeds have gained importance as foliar sprays and soil drench for many crops including various grasses, cereals, flowers and vegetable species.
Also they apply to stimulate seedling germination and rooting.

Improvement of yield and yield component by humic acid application can the effect of increasing of nutrients, especially phosphor and hormone-like effect of humic acid (Autio, 2000). The researchers reported that the humic acidby increasing the nitrogen content increases growth height, number of leaves, and yield (Ayas and Gulser, 2005).

The balance of fertilizer application is essential for the vegetative growth and, thus, for improving crops quality and yields especially on calcareous soils which are cultivated continuously. Improvement of management for macro and micronutrients in the soil could improve yields and quality of vegetables (Diriba et al.2013).

\subsection{Quality Growth Characters:}

Table (3) Indicated to the effect of humic acid and seaweeds extracts and their interaction on quality growth characteristic of garlic(bulbs diameter $\mathrm{cm}$,bulbs length $\mathrm{cm}$, cloves length $\mathrm{cm}$ and cloves diameter $\mathrm{cm})$ the data showed that there was significant differences according to the humic acid and Seaweeds extracts on bulbs diameter plant treated in the same time there was significant differences on bulbs diameter as a result of the concentration of humic acid on the other hand the effect of interaction between the treatment indicated that there was significant effect in the treatments, treating plant with concentration of seaweed extracts $\left(8 \mathrm{ml} . \mathrm{L}^{-1}\right)$ significantly increased which gave $(6.3 \mathrm{~cm})$ compared with untreated ones $(4.67$ $\mathrm{cm})$ the interaction between $\left(8 \mathrm{ml} . \mathrm{L}^{-1}\right)$ seaweeds extracts and treating plant with concentration(1and 1.5 g. $\mathrm{L}^{-1}$ ) of humic acid gave higher value of diameter $(6.87$ and $7.03 \mathrm{~cm})$ compared with other interaction especially untreated plants which gave lower diameter of bulbs $(5 \mathrm{~cm})$.

The results of the bulbs length $(\mathrm{cm})$ of garlic it also refers that the concentration of seaweeds extracts showed significant increase that, gave high length of bulbs $(4.16 \mathrm{~cm})$ compared with untreated plants that gave $(3.58 \mathrm{~cm})$ treating plant with 1.g.L- ${ }^{1}$ of humic acid gave highest length of bulbs that reached $(4.2 \mathrm{~cm})$ compared with untreated plants $(3.4 \mathrm{~cm})$. The interaction between using seaweeds extracts and humic acid it was showed that the interaction between 1.5 g.L $\mathrm{L}^{-}$ ${ }^{1}$ humic acid and $\left(8 \mathrm{ml} \cdot \mathrm{L}^{-1}\right)$ seaweeds extracts gave higher length of bulbs $(4.8 \mathrm{~cm})$ compared with control $(3.27 \mathrm{~cm})$.

The results in table (3) indicated cloves length (cm) The length was also significantly affected by 
concentration of humic acid ,the plant treated with (1 and 1.5g.L $\left.\mathrm{L}^{-1}\right) \mathrm{h}$ umic acid had higher length $(2.6$ and $2.72 \mathrm{~cm}$ ) respectively as compared with the control (2.33). It also indicates that $8 \mathrm{ml}^{-\mathrm{L}^{-}}$ ${ }^{1}$ seaweeds extracts with 1.5 g.L $\mathrm{L}^{-1}$ of humic acid significantly affected the length of cloves as compared with untreated plant of .It was showed that concentration $\left(8 \mathrm{ml} \mathrm{L}^{-1}\right)$ of seaweeds extract had high significant effects on length of cloves which reach $(2.82 \mathrm{~cm})$ than untreated plants $(2.29$ $\mathrm{cm})$.

The cloves diameter was showed significant different, treating plant with $1.5 \mathrm{~g} . \mathrm{L}^{-1}$ of humic acid gave high clove diameter $(2.67 \mathrm{~mm})$ as compared with control that gave lower value of diameter $(2.2 \mathrm{~mm})$. to using seaweeds extracts as compared with untreated plant (control) (2.85 and $2.14 \mathrm{~mm}$ ) respectively. The interaction among treatments showed significant different treating plants with $\left(1.5 \mathrm{~g} . \mathrm{L}^{-1}\right)$ that gave high diameter of stem $(3.6 \mathrm{~mm})$ compared with untreated plant that gave lower value (1.5 $\mathrm{mm})$.

The increase in quality characters may be due to increase of humic substances that increased organic matter in soil and reduce the negative effect of salt stress which increased yield of plants .,as well as, El-Bassiony et al. 2010 and El-Nemer et al. 2012 on sweet pepper plants.

Improvement for macro and micronutrients in the soil could improve yields and quality of vegetables and the same trend was found by Diriba et al. 2013 on garlic showed that effects of a balanced nutrients application on producing quality bulb of garlic combined applications of $92 \mathrm{~kg} \mathrm{~N}+40 \mathrm{~kg} \mathrm{P}+30 \mathrm{~kg} \mathrm{~S}$ ha-1 led to the attainment of optimum bulb quality.

Humic acid degrade soil, improve its physical, chemical, biological and nutritional characteristics by degrading clay particles and increasing holding water capacity. The increase in shoots characteristics might also be due to the auxins content in the seaweed extracts which have an effective role in cell division and enlargement; this leads to increase the shoot growth, leaves area and plant dry weight (Gollan and Wright, 2006).

Seaweed extracts has to equilibrium in growth as a result of the present auxins which will increase vitamins and hormones producing in the treated plants. As well as it contains GA3, GA7 and vitamin, Further than containing trace elements which are the most important sea plant components which is present in achelate state combined with iron in calkalius soils. It is available for plants. The chelate compounds are as carbohydrates combined with iron so it will be available to improve photosynthesis efficiency. (O’ Dell, 2003).

\subsection{Nutrient Content In Garlic Leaves:}

Table (4) indicated that the spraying plants with humic acid caused significant differences in the content of nitrogen as compared to the untreated plant, plant treated with concentration (1.5 g.L) of humica cid gave significant increase which gave high percentage of nitrogen $(4.65 \%)$ as compared with untreated plant (3.83\%).

The interaction between plant treated with $(8$ $\left.\mathrm{ml} . \mathrm{L}^{-1}\right)$ Seaweeds extract and $\left(1 \mathrm{~g} . \mathrm{L}^{-1}\right)$ humic acid gave high value of nitrogen percentage $(4.5 \%)$ as compared with untreated interaction (3.66 and $3.88 \%$ ). As well plant treated Seaweed extracts positive significant effects as comparison with untreated plant, treating plant with $\left(8 \mathrm{ml} . \mathrm{L}^{-1}\right)$ of seaweeds gave high percentage of nitrogen $(4.4 \%)$ as compared with untreated plant $(4.12 \%)$.

Results in the table(4) also showed that humic acid and seaweeds extracts gave significant different on regard of phosphorus percentage, plant spraying with different value of humic acid gave significant effects as compared with other treatments $(0.5 \%)$. The interaction effect among seaweeds extract and humic acis significantly effect on $\mathrm{P}$ percentages, using of $\left(8 \mathrm{ml} . \mathrm{L}^{-1}\right)$ of seaweeds extract with $(1.5 \mathrm{gm} . \mathrm{L})$ of humic acid gave high value of phosphorus percentage $(0.54 \%)$ in comparison with untreated plants $(0.21 \%)$. treating plant $\left(8 \mathrm{ml} . \mathrm{L}^{-1}\right)$ of seaweeds extracts gave high value of phosphorus percentage $(0.44 \%)$ as compared with control( $0.33 \%)$,

Data presented in Table (4) obviously showed that seaweeds extracts caused significant increase on regard of potassium $\%$ as compared with control(2.15 and 1.99\%), treating plant with different concentration of humic acid caused significant effect on potassium percentage as compared to untreated plants. Regarding the interaction among seaweeds extract and concentration of humic acid it was indicated that plant treated with $\left(1.5\right.$ g.L $\left.\mathrm{L}^{-1}\right)$ of humic acid and $(8$ ml. $\mathrm{L}^{-1}$ ) seaweeds extract gave high value of potassium percentage $(2.66 \%)$ as compared with other interaction especially untreated interaction $(1.7 \%)$.

The positive effects of addition treatments may be due to the effect of humic acid and seaweed extract which influence plant chemical composition directly and indirectly. The indirect effects of humic compounds on soil fertility include, Furthermore, directly; humic acid compounds may have various biochemical effects either at cell wall membrane level or in the cytoplasm. 
In another study, humic substances may possibly enhance the uptake of minerals through the stimulation of microbiological activity (Gad El-Hak et al. 2012 and Manas et al.2014). The same trend was found by, ElBassiony et al. 2010, El-Nemer et al. 2012, Denre et al.
2014 and Shafeek et al. 2014 and Shafeek et al.2015) humic acid maintaince photosynthetic tissues and increase the yield by positive effects on cellular metabolism sand increases of leaf chlorophyll (Naderi et al.,

2002).

Table (1): Effect of Humic acid, Seaweeds extract and their interaction on vegetative growth characteristic of garlic.

\begin{tabular}{|c|c|c|c|c|c|c|c|c|c|c|}
\hline \multirow{3}{*}{$\begin{array}{c}\text { Seaweed } \\
\text { extracts }\left(m \mathrm{ml} \cdot \mathrm{L}^{-1}\right)\end{array}$} & \multirow{2}{*}{\multicolumn{4}{|c|}{$\begin{array}{l}\text { Leaves length }(\mathrm{cm}) \\
\text { Humic acid }\left(\mathrm{g} \cdot \mathrm{L}^{-1}\right)\end{array}$}} & \multirow{3}{*}{$\begin{array}{c}\text { effect of } \\
\text { Effect of } \\
\text { seaweeds } \\
\text { extracts }\end{array}$} & \multirow{2}{*}{\multicolumn{4}{|c|}{$\frac{\text { leaves number.plant }^{-1}}{\text { Humic acid }\left(\mathbf{g} \cdot \mathrm{L}^{-1}\right)}$}} & \multirow{3}{*}{$\begin{array}{l}\text { effect of } \\
\text { Seaweeds } \\
\text { extracts }\end{array}$} \\
\hline & & & & & & & & & & \\
\hline & 0 & 0.5 & 1 & 1.5 & & 0 & 0.5 & 1 & 1.5 & \\
\hline 0 & $53.67 \mathrm{c}$ & $58.67 \mathrm{bc}$ & $63.33 \mathrm{ab}$ & $58.7 \mathrm{bc}$ & $58.6 \mathrm{~b}$ & $4.33 c$ & $4.73 b c$ & $5 b$ & $5.33 \mathrm{~b}$ & $4.85 \mathrm{~b}$ \\
\hline 8 & $59.33 \mathrm{bc}$ & $59 \mathrm{bc}$ & $67.67 \mathrm{a}$ & $63.3 a b$ & $62.3 a$ & $4.67 \mathrm{bc}$ & $6.65 a$ & $6.88 \mathrm{a}$ & $6.67 a$ & $6.21 \mathrm{a}$ \\
\hline $\begin{array}{l}\text { effect of humic } \\
\text { acid }\end{array}$ & $56.5 b$ & $58.83 b$ & $65.5 a$ & $61 a b$ & & $4.5 b$ & $5.7 a b$ & $5.94 a b$ & $6 a$ & \\
\hline \multirow{3}{*}{$\begin{array}{c}\text { Seaweed } \\
\text { extracts }\left(m \mathrm{ml} \mathrm{L}^{-1}\right)\end{array}$} & \multicolumn{4}{|c|}{ Stem diameter $(\mathrm{mm})$} & Effect of & \multicolumn{4}{|c|}{ Chlorophyll (SPAD) } & \multirow{3}{*}{$\begin{array}{l}\text { Effect of } \\
\text { seaweeds } \\
\text { extracts }\end{array}$} \\
\hline & \multicolumn{4}{|c|}{ Humic acid $\left(\mathrm{g} \cdot \mathrm{L}^{-1}\right)$} & seaweeds & \multicolumn{4}{|c|}{ Humic acid $\left(\mathrm{g} \cdot \mathrm{L}^{-1}\right)$} & \\
\hline & 0 & 0.5 & 1 & 1.5 & extracts & 0 & 0.5 & 1 & 1.5 & \\
\hline 0 & $3.13 \mathrm{c}$ & $4.73 b$ & $5 a b$ & $5.33 a b$ & $4.55 b$ & $51.67 \mathrm{c}$ & $63.33 b$ & $63.97 \mathrm{~b}$ & $64.77 \mathrm{~b}$ & $60.93 b$ \\
\hline 8 & $4.53 b$ & $5 a b$ & $5.88 a$ & $5.99 a$ & $5.35 a$ & $62.9 \mathrm{~b}$ & $65.4 b$ & $70.3 a b$ & $74.8 \mathrm{a}$ & $68.35 a$ \\
\hline $\begin{array}{l}\text { effect of humic } \\
\text { acid }\end{array}$ & $3.83 c$ & $4.87 \mathrm{~b}$ & $5.66 a b$ & $5.6 a$ & & $57.28 b$ & $64.37 a$ & $67.13 a$ & $69.78 a$ & \\
\hline
\end{tabular}

Means within a column, row and their interactions followed with the same letters are not significantly different from each other according to Duncan's multiple range test at 5\% level.

Table (2): Effect of Humic acid, Seaweeds extract and their interaction on yield of garlic.

\begin{tabular}{|c|c|c|c|c|c|c|c|c|c|c|}
\hline \multirow{3}{*}{$\begin{array}{l}\text { Seaweed } \\
\text { extracts }\left(m l . L^{-1}\right)\end{array}$} & \multicolumn{4}{|c|}{ Cloves weight (g) } & \multirow{3}{*}{$\begin{array}{l}\text { effect of } \\
\text { seaweeds } \\
\text { extracts }\end{array}$} & \multicolumn{4}{|c|}{ Cloves number } & \multirow{3}{*}{$\begin{array}{c}\text { effect of } \\
\text { seaweeds } \\
\text { extracts }\end{array}$} \\
\hline & \multicolumn{4}{|c|}{ Humic acid $\left(g . L^{-1}\right)$} & & \multicolumn{4}{|c|}{ Humic acid $\left(g \cdot L^{-1}\right)$} & \\
\hline & 0 & 0.5 & 1 & 1.5 & & 0 & 0.5 & 1 & 1.5 & \\
\hline 0 & $3.58 \mathrm{c}$ & 4.1ab & $4.93 a b$ & $4.4 a b$ & $4.25 b$ & $5.33 b$ & $7 a b$ & 7.33ab & $7.67 a$ & $6.83 b$ \\
\hline 8 & $3.83 \mathrm{c}$ & $4.5 a b$ & $4.67 a b$ & $5.4 a$ & $4.6 a$ & 7.33ab & $7.67 a$ & $7.79 a$ & $7.68 \mathrm{a}$ & $7.61 \mathrm{a}$ \\
\hline $\begin{array}{c}\text { Effect of humic } \\
\text { acid }\end{array}$ & $3.70 \mathrm{~b}$ & $4.3 a$ & $4.8 \mathrm{a}$ & $4.9 a$ & & $6.33 c$ & 7.33ab & $7.59 a b$ & $7.67 a$ & \\
\hline
\end{tabular}

\begin{tabular}{|c|c|c|c|c|c|c|c|c|c|c|}
\hline \multirow{3}{*}{$\begin{array}{c}\text { Seaweed } \\
\text { extracts }\left(m l^{\left.-L^{-1}\right)}\right.\end{array}$} & \multicolumn{4}{|c|}{ Bulbs weight (g) } & \multirow{3}{*}{$\begin{array}{l}\text { effect of } \\
\text { seaweeds } \\
\text { extracts }\end{array}$} & \multicolumn{4}{|c|}{ Total yield $\left(\mathrm{kg} . \mathrm{m}^{2}\right)$} & \multirow{3}{*}{$\begin{array}{l}\text { effect of } \\
\text { seaweeds } \\
\text { extracts }\end{array}$} \\
\hline & \multicolumn{4}{|c|}{ Humic acid $\left(\mathrm{g} . \mathrm{L}^{-1}\right)$} & & \multicolumn{4}{|c|}{ Humic acid $\left(g \cdot \mathrm{L}^{-1} 0\right.$} & \\
\hline & 0 & 0.5 & 1 & 1.5 & & 0 & 0.5 & 1 & 1.5 & \\
\hline 0 & $22.50 d$ & $22.67 b$ & $24.47 b$ & $26.97 a-b$ & $24.15 b$ & $90 d$ & $90.7 \mathrm{bc}$ & $107.9 a b$ & $97.88 \mathrm{~b}$ & $96.6 b$ \\
\hline 8 & $22.67 c$ & $24.77 \mathrm{bc}$ & $31.93 a$ & $29.97 a b$ & $27.33 a$ & $90.68 c$ & $99.1 \mathrm{bc}$ & $119.9 a b$ & $127.72 a$ & $109.32 a$ \\
\hline $\begin{array}{c}\text { effect } \\
\text { of Humic acid }\end{array}$ & $22.67 c$ & $23.63 b$ & $28.20 \mathrm{a}$ & $28.47 a$ & & $90.68 c$ & $94.9 b$ & $113.9 \mathrm{a}$ & $112.8 a b$ & \\
\hline
\end{tabular}

Means within a column, row and their interactions followed with the same letters are not significant different from each other according to Duncan's multiple range test at 5\% level. 
Table (3): Effect of humic acid, Seaweeds extract and their interaction on quality characteristic of garlic..

\begin{tabular}{|c|c|c|c|c|c|c|c|c|c|c|}
\hline \multirow{3}{*}{$\begin{array}{c}\text { Seaweed } \\
\text { extracts }\left(m l . L^{-1}\right)\end{array}$} & \multicolumn{4}{|c|}{ Bulbs diameter(cm) } & \multirow{3}{*}{$\begin{array}{l}\text { Effect of } \\
\text { seaweeds } \\
\text { extracts }\end{array}$} & \multicolumn{4}{|c|}{ Bulbs length (cm) } & \multirow{3}{*}{$\begin{array}{c}\text { Effect of } \\
\text { seaweeds } \\
\text { extracts }\end{array}$} \\
\hline & \multicolumn{4}{|c|}{ Humic acid (g. $\left.\mathrm{L}^{-1}\right)$} & & \multicolumn{4}{|c|}{ Humic acid (g. $\left.\mathrm{L}^{-1}\right)$} & \\
\hline & 0 & 0.5 & 1 & 1.5 & & 0 & 0.5 & 1 & 1.5 & \\
\hline 0 & $5 c$ & $5.67 \mathrm{bc}$ & $6.67 a b$ & $4.67 \mathrm{c}$ & $5.5 b$ & $3.27 \mathrm{c}$ & $3.43 a-c$ & $3.87 a-c$ & 3.77 & $3.58 b$ \\
\hline 8 & $5.67 \mathrm{bc}$ & $5.27 \mathrm{c}$ & $7.4 \mathrm{a}$ & $6.87 a$ & $6.3 a$ & $3.67 a-c$ & $3.73 a-c$ & $4.43 a b$ & $4.8 \mathrm{a}$ & $4.16 \mathrm{a}$ \\
\hline $\begin{array}{c}\text { Effect of } \\
\text { humic acid }\end{array}$ & $5.33 b$ & $5.47 b$ & $7.03 a$ & $5.77 \mathrm{~b}$ & & $3.47 \mathrm{~b}$ & $3.58 a b$ & $4.15 a b$ & $4.28 \mathrm{a}$ & \\
\hline \multirow{3}{*}{$\begin{array}{c}\text { Seaweed } \\
\text { extracts }\left(\mathrm{ml} . \mathrm{L}^{-}\right. \\
1 \text { ') }\end{array}$} & \multicolumn{4}{|c|}{ Cloves length (cm) } & Effect of & \multicolumn{4}{|c|}{ Cloves diameter $(\mathrm{cm})$} & Effect of \\
\hline & \multicolumn{4}{|c|}{ Humic acid $\left(\mathrm{g} . \mathrm{L}^{-1}\right)$} & seaweeds & \multicolumn{4}{|c|}{ Humic acid $\left(\mathrm{g} \cdot \mathrm{L}^{-1}\right)$} & seaweeds \\
\hline & 0 & 0.5 & 1 & 1.5 & extracts & 0 & 0.5 & 1 & 1.5 & extracts \\
\hline 0 & $2.00 b-d$ & $2.37 b-d$ & $2.27 b-d$ & $2.28 a-c$ & $2.29 b$ & $1.5 b$ & $2.87 a b$ & $1.67 \mathrm{~b}$ & $2.53 a b$ & $2.14 b$ \\
\hline 8 & $2.63 a-c$ & $2.8 \mathrm{ab}$ & $2.95 a$ & $2.82 \mathrm{a}$ & $2.82 \mathrm{a}$ & $2.9 a b$ & $2.13 a$ & $3.6 a$ & $2.8 \mathrm{ab}$ & $2.85 a$ \\
\hline $\begin{array}{c}\text { Effect of } \\
\text { humic acid }\end{array}$ & $2.31 b$ & $2.58 a b$ & $2.6 a b$ & $2.72 a$ & & $2.2 \mathrm{~b}$ & $2.5 a b$ & $2.63 a b$ & $2.67 a$ & \\
\hline
\end{tabular}

Means within a column, row and their interactions followed with the same letters are not significantly different from each other according to Duncan's multiple range test at 5\% level.

Table (4): Effect of humic acid ,Seaweeds extract and their interaction on nutrient contentgarlic of garlic.

\begin{tabular}{|c|c|c|c|c|c|c|c|c|c|c|}
\hline \multirow{3}{*}{$\begin{array}{c}\text { Seaweed } \\
\text { extracts }\left(\mathrm{ml} . \mathrm{L}^{-}\right. \\
\left.{ }^{1}\right)\end{array}$} & \multicolumn{4}{|c|}{ Nitrogen\% } & \multirow{3}{*}{$\begin{array}{l}\text { Effect of } \\
\text { seaweeds } \\
\text { extracts }\end{array}$} & \multirow{2}{*}{\multicolumn{4}{|c|}{$\begin{array}{c}\text { Phosphorus\% } \\
\text { Humic acid }\left(\mathrm{g} . \mathrm{L}^{-1}\right)\end{array}$}} & \multirow{3}{*}{$\begin{array}{c}\text { Effect of } \\
\text { seaweeds } \\
\text { extracts }\end{array}$} \\
\hline & \multicolumn{4}{|c|}{ Humic acid $\left(\mathrm{g} \cdot \mathrm{L}^{-1}\right)$} & & & & & & \\
\hline & 0 & 0.5 & 1 & 1.5 & & 0 & 0.5 & 1 & 1.5 & \\
\hline 0 & $3.66 \mathrm{c}$ & $4.2 b$ & $4.0 \mathrm{~b}$ & $4.1 \mathrm{~b}$ & $3.99 b$ & $0.21 f$ & $0.31 \mathrm{e}$ & $0.35 \mathrm{de}$ & $0.45 b$ & $0.33 b$ \\
\hline 8 & $3.88 \mathrm{c}$ & $4.22 b$ & $4.22 \mathrm{ab}$ & $4.5 a$ & $4.4 \mathrm{a}$ & $0.42 \mathrm{bc}$ & $0.38 \mathrm{~cd}$ & $0.40 b-d$ & $0.54 a$ & $0.44 a$ \\
\hline $\begin{array}{l}\text { Effect of } \\
\text { seaweed } \\
\text { extracts }\end{array}$ & $3.77 \mathrm{c}$ & $4.21 b$ & $4.65 a$ & 4.3ab & & $0.32 \mathrm{c}$ & $0.34 \mathrm{bc}$ & $0.38 b$ & $0.5 a$ & \\
\hline \multirow{3}{*}{$\begin{array}{c}\text { Seaweed } \\
\text { extracts }\left(\mathrm{ml} . \mathrm{L}^{-}\right. \\
\left.{ }^{1}\right)\end{array}$} & \multicolumn{4}{|c|}{ Potassium \% } & \multirow{3}{*}{$\begin{array}{l}\text { Effect of } \\
\text { seaweeds } \\
\text { extracts }\end{array}$} & & & & & \\
\hline & \multicolumn{4}{|c|}{ Humic acid (g. $\left.\mathrm{L}^{-1}\right)$} & & & & & & \\
\hline & 0 & 0.5 & 1 & 1.5 & & & & & & \\
\hline 0 & $1.7 \mathrm{c}$ & $1.77 \mathrm{~d}$ & $1.99 \mathrm{bc}$ & $2.5 a b$ & $1.99 \mathrm{~b}$ & & & & & \\
\hline 8 & $1.73 c$ & $2.16 \mathrm{~b}$ & $2.06 \mathrm{bc}$ & $2.63 a$ & $2.15 \mathrm{a}$ & & & & & \\
\hline $\begin{array}{l}\text { Effect of } \\
\text { seaweeds } \\
\text { extracts }\end{array}$ & $1.71 \mathrm{c}$ & $1.96 \mathrm{~b}$ & $2.03 b$ & $2.57 a$ & & & & & & \\
\hline
\end{tabular}

Means with column, row and their interactions followed with the same letters are not significantly different from each other according to Duncan's multiple range test at 5\% level. 


\section{REFERENCES}

-A.O.A.C. (2000). "Official Method of Analysis" $11^{\text {th }}$ edition Washington D.C. Association of official analysis chemist.P. 1015 .

-Abdel-Mawgoud, A. M. R. ; N. H. M, El- Greudy, Y. I. Helmy and S. M. Singer (2007). Responses of tomato plants to different rates of humic based fertilizer and NPK fertilization. J. Applied Sci. Research. 3(2):169-174.

-Abdel-Razzak, H.S., G.A. El-Sharkawy, (2013). Effect of Biofertilizer and humic acid applications on growth, yield, quality and storability of two garlic (Allium sativum L.) Cultivars. Asian J. of Crop Sci., 5: 48-64.

-Attememe. J. Y. A. (2009). The effect of humic acid and sea weed extracts on the growth, chemical characteristics and oil characteristics of Rosmarinus officinalis L. the 6thscientific conference, Biology Dept., College of Education , University of Tikrit. Plants Sci. P. 1-17.

-Autio, J. (2000). Supplementary lighting regimes strongly affect the quantity of gerbera flower yield.Acta Hort. 515: 91-98.

-Ayas, H. and F. Gulser. (2005). The effect of sulfur and humic acid on yield components and macronutrient contents of spinach (Spinacia Oleracea Var. Spinoza). Journal of Biological Sciences. 5(6):801-804.

-Craigie, J .S. (2011). Seaweed extract stimuli in plant science and agriculture. J. Appl. Phycol. 23: 371 -393 .

-Denre, M., SoumyaGh. And Sh.Kheyali, (2014).Effect of humic acid application on accumulation of mineral nutrition and pungency in garlic (Allium sativum L.) Int. J. Biotechnol. Mol. Biol. Res., 5(2): 7-12 .

-Diriba-Sh, G., D.R. Nigussie, W. Kebede, T. Getachew and J.J. Sharma, (2013).Bulb quality of garlic (Allium sativum L.) as influenced by the application of inorganic fertilizers. Afr. J. Agric. Res., 8(43): 5387-5398.

-El-Bassiony, A.M., Z.F. E.H. Fawzy, G.S Abd ElSamad, (2010).Riad growth, yield and fruit quality of sweet pepper plants (Capsicum annuum L.) as affected by potassium fertilization.J. of Ameri.Sci., 6(12).

-El-Nemer, M.A. : M. El-Desuki, A.M. El-Bassiony and Z.F. Fawzy, (2012). Response of growth and yield of cucumber plants (Cucumissativus L.) to different foliar applications of humic acid and bio-stimulators. Aust. J. Basic. Appl. Sci., (6): 630-637.

-El-Sharkawy, G.A. and H.S. Abdel-Razzak. (2010). Response of cabbage plants (Brassica oleraceae var. capitata L.) to fertilization with chicken manure, mineral nitrogen fertilizer and humic acid. Alex SciExch J., 31: 416-432.

-Eris, A., H. O. Sirritepe and N. Sirritepe ,(2008). The effect of seaweed (Ascophyllumnodosum) Extract on yield and quality criteria in pipers. ActaHorti. (ISHS) 412:733-737.

-Gad El-Hak, S.H., A.M. Ahmed and Y.M.M. Moustafa, (2012). Effect of foliar application with two antioxidants and humic acid on growth, yield and yield components of peas (Pisumsativum L.). J. of Hort. Sci., 4(3): 318328.

-Gaines I, and Yilmaz A (1983). Comparison of five humicacid. Fuel. 62: 373-379.

-Garcia, M. C. V., F. S. Estrella, M. J. Lopez and J. Moreno (2008). Influence of compost amendment on soil biological properties and plants. Dynamic Soil, Dynamic Plant. 1. 1-9.

-Gollan, J. R. and J. T. Wright (2006). Limited grazing pressure by native herbivores on the invasive seaweed caulerpa. Taxi folia in a temperate.Australia Estuary Marine and Freshwater Research. 57(7):685-694.

-Hahn, G. (1996). History, folk medicine, and legendary uses of garlic. In: H.P. Kock and L.D. Lawson (eds.). Garlic: The science and therapeutic application of Allium sativum L. and related species. Williams and Wilkins, Baltimore.

-Hilman, Y., A.A. Asandhi, (1987). Effect of several kinds of foliar fertilizer and plant growth regulator on the growth and yield of garlic Allium sativum L. cv. LumbuHijau in the rainy season. Bull. PenelitianHortikult, 151(2): 267272.

-Hong, D. D., H. M. Hien and P. N. Son. (2007). Seaweeds from Vietnam used for functional food, medicine and biofertilizer. J. Appl. Phycol. 19: 817 -826. 
-Jensen, E. (2004) Seaweed; Fact or Fanc. From the Organic Broadcaster, From the Broad Caster. 12(3): 164-170.

-Kumari, R., I. Kaur., and A. K. Bhatnagar. (2011). Effect of aqueous extract of SargassumjohnstoniiSetchel\& Gardner on growth, yield and quality of Lycopersiconesculentum Mill. J. Appl. Phycol. 23: $623-633$.

-Leonard, A. G. (2008). Humic acid: 100\% Natural, Many Uses. Goldend Harvest organic.LLCTM.

-Manas D., SoumyaGh. and Kh. Sarkar, (2014).Effect of humic acid application on accumulation of mineral nutrition and pungency in garlic (Allium sativum L.) cultivars. Int. J. Biot. Mol. Biol. Res., 5(2): 7-12.

-Matt, J. ((1970). "Calorimetric Determination of Phosphorus in Soil and Plant Material with Ascorbic Acid”. Soil. Sci., Vol.(109), pp. 219220.

-Naderi, S., Pizzeghello, D., Muscolo, A., Vianello, A. (2002).Physiological effects of humic substances on higher plants. Soil Biology and Biochemistry. 34, 1527-1536.

-O’ Dell, C. (2003). Natural plant hormones are bio stimulants helping plants develop high plant antioxidant Activity for multiple benefits. Virginia Vegetable, Small Fruit and Specialty Crops. 2(6):1-3.

-Shafeek, M.R. H.A. : R.M Aisha,. Asmaa, M.H. Magda and F.A. Rizk, (2015). Improving growth and productivity of garlic plants (Allium sativum L.) as affected by the addition of organic manure and humic acid levels in sandy soil conditions. Int. J.Curr.Microbiol.App. Sci., 4(9): 644-656.

-Shafeek, M.R.: Y.I. Helmy and M.M.B. Shokr, (2014). Response of hot pepper (Capsicum annum L.) to nitrogen fertilizer and humic acid levels under sandy soil conditions in plastic house. Middle East J. Agric. Res., 3(2): 235-241.

-Stevenson F.J (1994). Cycles of soil.Carbon, nitrogen, phosphorous, sulfur and micronutrients.Jhon Wiley and Sons, Inc. New York.

-Thomas, S. C. L. (1996). Nutrient weeds as soil amendmen.Published by Moses the Midwest Organic and Sustainable Education.

-Thomas, S. C. L. (1996). Nutrient weeds as soil amendments for organic cally growth herbs.Jour of Herbs, Spices and Medicinal Plant. 4(1): 3-8.

-Thomas, S. C. L. (1996). Nutrient weeds as soil amendments for organic cally growth herbs.Jour of Herbs, Spices and Medicinal Plant. 4(1): 3-8.

-Zhang, X. Z. and E.H. Ervin. (2004). Cytokinincontainingseaweed and humic acid extracts associated with creeping bentgrass leaf cytokinins and drought resistance. Crop Sci. 44: $1737-1745$.

-Zodape, S.T.; V. J. Kawarkhe., J. S. Patolia. And A. D. Warade. (2008). Effect of liquid seaweed fertilizer on yield and quality of okra (Abelmoschus esculentus L.). J. Sci. Ind. Res. 67:

1115

-1117 . 
كارتيكرنا ترشنّ هيوميك و كيايينّذهرياينّلسهركهشهرنابهرههئينان و ناقهروكاكانز ايان بو سيريّ (Allium sativum $\mathbf{L}$ )

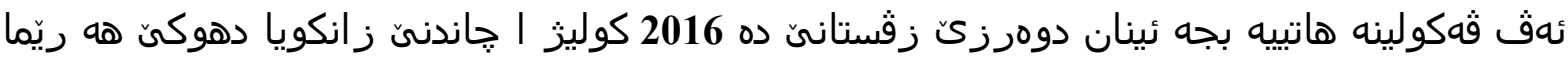

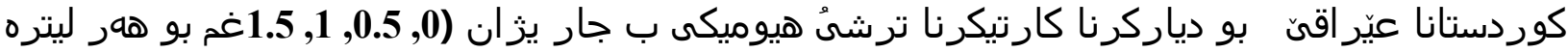

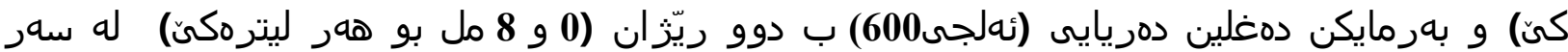

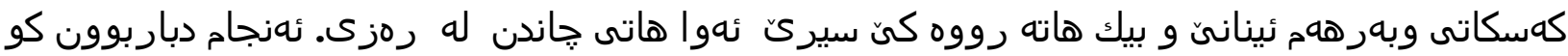

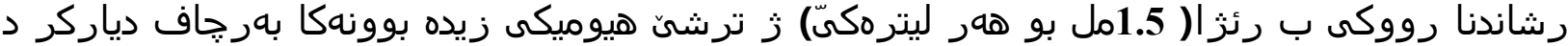

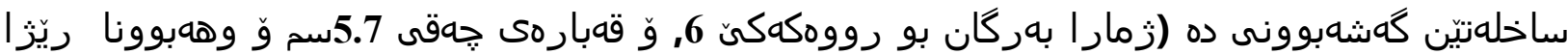

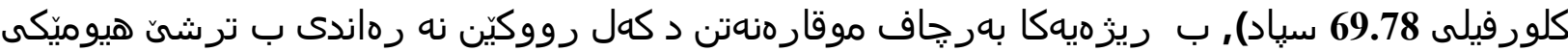

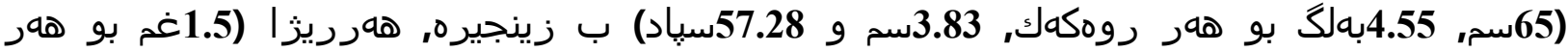

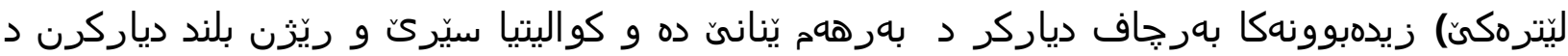

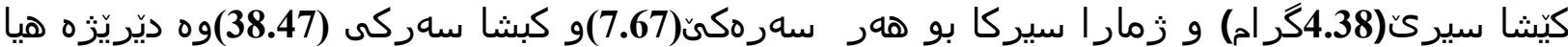

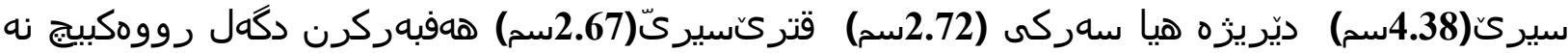

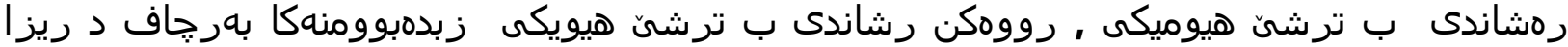

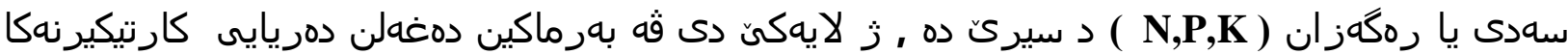

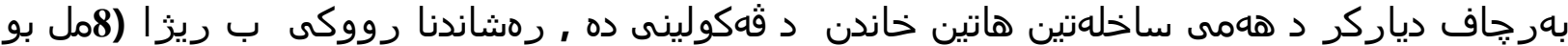

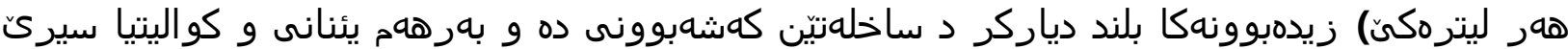

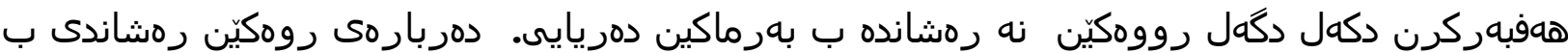

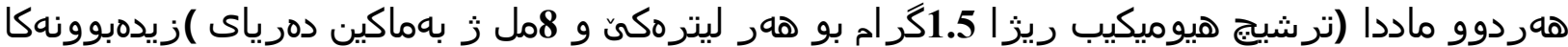

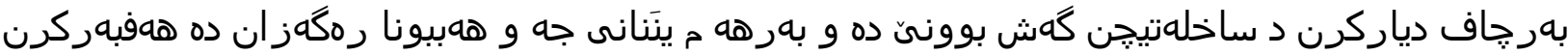

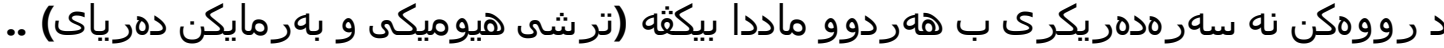

تاثير حامض الهيوميك والمستخلصات البحرية ,في نمو, حاصل ومحتوى المغذيات للثوم Allium sativum ( L)

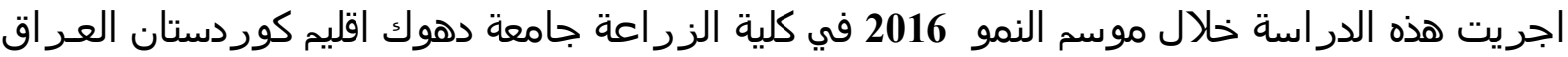

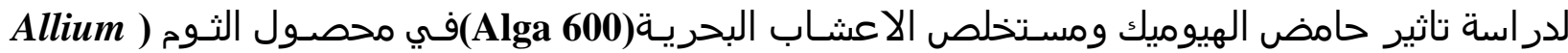

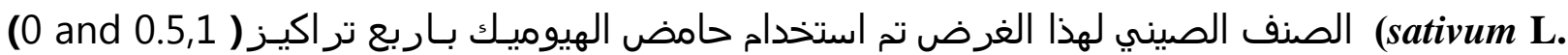
and 1.5 g.L-1 
الحقل.اظهرت النتائج بان رش النباتات ب (1.5مل لكل لتر) من حامض الهيوميك تغوق معنويا في صفات الحفات

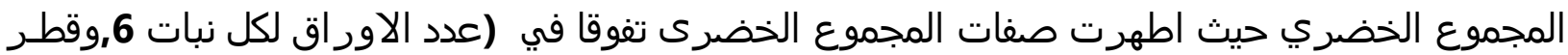

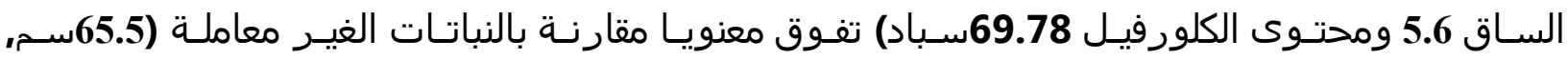

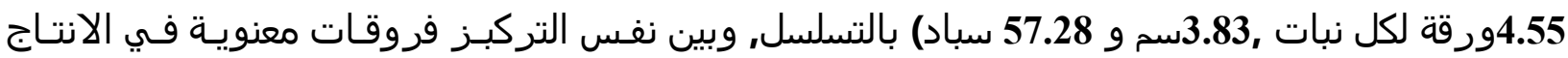

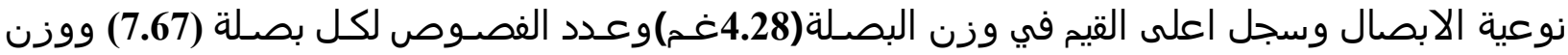

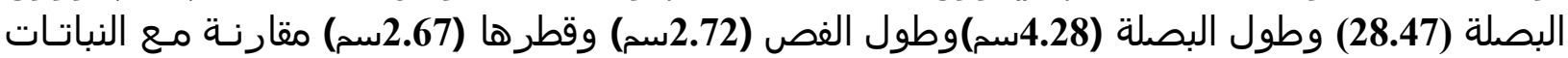

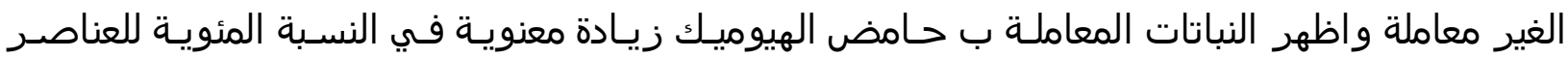

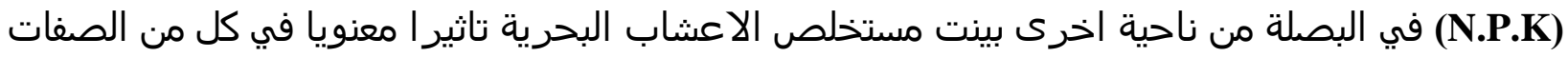

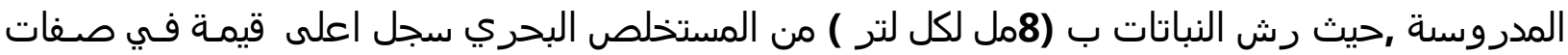

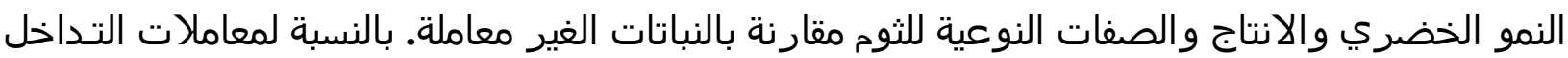

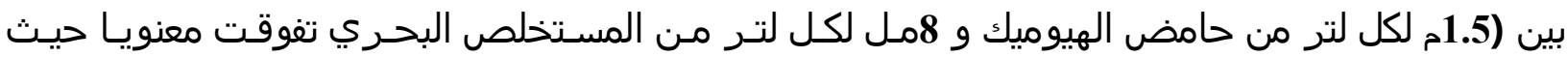
اعطى اعلى القيم للنمو الخضري والانتانتاج ومحتوى المغذيات. 